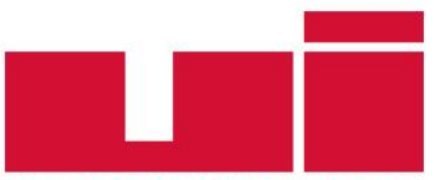

ULLUSLARARASIILIȘKiLER

Akademik Dergi

Yayın ilkeleri, izinler ve abonelik hakkında ayrıntılı bilgi:

E-mail: bilgi@uidergisi.com.tr

Web: www.uidergisi.com.tr

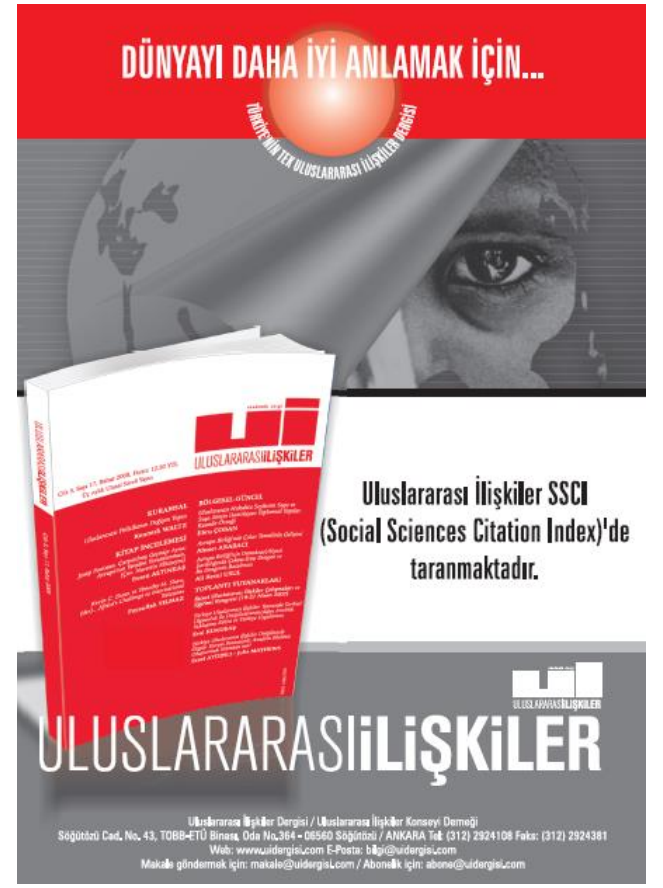

\title{
Mülteci Sorunu ve 1951 Mültecilerin Hukuki \\ Durumuna İlişkin Sözleşme: Siyasi Gerçeklik ve Normatif Düzen İkilemi
}

\author{
Arzu GÜLER* \\ * Yrd. Doç. Dr., Uluslararası İlișkiler Bölümü, Adnan Menderes \\ Üniversitesi
}

Bu makaleve atıf için: Güler, Arzu, "Mülteci Sorunu ve 1951 Mültecilerin Hukuki Durumuna Illişkin Sözleşme: Siyasi Gerçeklik ve Normatif Düzen İkilemi”, Uluslararası İlişkiler, Cilt 13, Sayı 51, 2016, s. 41-61.

Bu makalenin tüm hakları Uluslararası İlişkiler Konseyi Derneği'ne aittir. Önceden yazılı izin alınmadan hiç bir iletişim, kopyalama ya da yayın sistemi kullanılarak yeniden yayımlanamaz, çoğaltılamaz, dağıtılamaz, satılamaz veya herhangi bir şekilde kamunun ücretli/ücretsiz kullanımına sunulamaz. Akademik ve haber amaçlı kısa alıntılar bu kuralın dışındadır.

Aksi belirtilmediği sürece Uluslararası Illişkiler'de yayınlanan yazılarda belirtilen fikirler yalnızca yazarına/yazarlarına aittir. UIKK Derneğini, editörleri ve diğer yazarları bağlamaz. 


\title{
Mülteci Sorunu ve 1951 Mültecilerin Hukuki Durumuna İlişkin Sözleşme: Siyasi Gerçeklik ve Normatif Düzen İkilemi
}

\author{
Arzu GÜLER \\ Yrd. Doç. Dr., Uluslararası İlişkiler Bölümü, Nazilli İİBF, Adnan Menderes Üniversitesi, Nazilli, Aydın. \\ E-posta: arzuguler@adu.edu.tr.
}

\begin{abstract}
ÖZET
İnsanlık, 2. Dünya Savaşı́ndan bu yana yaşanan en ciddi mülteci sorunu ile karşı karşıyadır. Sorunun ciddiyetine karşın devletlerin mülteci sorununa ilişkin politikaları, 1951 Sözleşmesi’nde amaçlandığının aksine mültecilerin korunması ve sorumluluk paylaşımı mekanizmasından oldukça uzaktır. Sadece 5 ülke tek başına dünyadaki mültecilerin \%33'üne ev sahipliği yapmakta, her 10 mülteciden 9'u gelişmekte olan devletlerde bulunmakta ve mültecilerin \%1’i dahi üçüncü bir ülkeye yerleştirme ve yerel bütünleşme kalıcı çözümlerine erişememektedir. Mevcut literatür genel olarak bu krizin nedenlerine odaklanırken; bu çalışma uluslararası bir rejimin ve bağlayıcı bir sözleşmenin kurduğu normatifbir düzenin varlığına rağmen, taraf devletlerin mülteci sorununa yönelik politikalarını nasıl hâlâ kendi davranışlarına, isteklerine ve çıkarlarına göre şekillendirebildiklerini sorgulamaktadır. Çalışma; bu soruyu 1951 Sözleşmesi’ni mülteci tanımı, uluslararası koruma ve sorumluluk paylaşımı açısından inceleyerek cevaplamaya çalışmaktadır. Çalışmaya göre Sözleşme, muğlâk ve göreceli ifadelere sahip yapısı ile taraf devletlere mülteci sorunuyla ilgili politikalarını siyasi gerçekliklere göre şekillendirebilme imkânı sunarak günümüzde yaşanan krize olanak tanımaktadır.
\end{abstract}

Anahtar Kelimeler: Uluslararası Mülteci Rejimi, 1951 Sözleşmesi, Mülteci, Uluslararası Koruma, Sorumluluk Paylaşımı.

\section{Refugee Problem and the 1951 Convention Relating to the Status of Refugees: The Dichotomy Between Political Realism and Normative Order}

\begin{abstract}
The humanity experiences the most serious refugee problem since the Second World War. Despite the nature of the problem, states' policies on refugee problem are far away from protecting refugees and from providing responsibility sharing mechanism, being contrary to the aims of 1951 Convention. 5 states alone host $83 \%$ of the world's refugees, 9 out of 10 refugees are in developing states and not even $1 \%$ of the refugees could have access to durable solutions such as third country resettlement and local integration. While existing literature mainly focuses on the reasons of this crisis, this study questions how state parties can still shape their policies on refugee problem according to their behaviors, will and interests despite the existence of an international regime and a binding agreement. The study seeks to answer this question by examining 1951 Convention in terms of refugee definition, international protection and responsibility sharing. The study argues that the Convention with its structure of vague and relative statements facilitates current crisis by enabling states to shape their policies on refugee problem according to political realities.
\end{abstract}

Keywords: International Refugee Regime, 1951 Convention, Refugee, International Protection, Responsibility Sharing. 


\section{Giriş}

İkinci Dünya Savaşı́ndan bu yana dünyada 300'den fazla silahlı çatışma yaşanmış, bu çatışmalarda 100 milyondan fazla insan hayatını kaybederken milyonlarca kişi de mülteci konumuna düşmüştür. ${ }^{1}$ Zulümden, çatışmadan, genel şiddet ve insan hakları ihlallerinden kaçan kişi sayısı 2. Dünya Savaşı'ndan bu yana ilk defa 2014 yılında 50 milyonu aşarak 51,2 milyon olmuş; 2015 yılı sonunda ise şimdiye kadar kaydedilen en yüksek artışla 65,3 milyona ulaşmıştır. Son 3 yılda Suriye'deki savaş başta olmak üzere Afganistan, Burundi, Demokratik Kongo Cumhuriyeti, Güney Sudan ve Ukrayna'daki çatışmalar nedeniyle dünyadaki toplam mülteci sayısı ise \%57 oranında artarak 21,3 milyon olmuştur. ${ }^{2}$ Hiçbir devletin tek başına üstesinden gelemeyeceği uluslararası bir sorun olan mülteci sorununa ilişkin bir rejimin kurulmasının üzerinden neredeyse yüzyıl geçmiş ${ }^{3}$ ancak uluslararası mülteci rejiminin koruma ve sorumluluk paylaşımı mekanizmasına belki de şimdiye kadar hiç bu kadar güçlü bir şekilde ihtiyaç duyulmamıştır.

2015 yılında devletlerin iltica hakkını tanımayacak şekilde ${ }^{4}$ sınırlara dikenli teller ve duvarlar örmesi nedeniyle Akdeniz'i geçerek Avrupa'ya ulaşmaya çalışan 3770 kişi hayatını kaybetmiştir. ${ }^{5}$ İltica hakkının tanınmamasının yanı sıra devletlerin geri göndermeme ilkesini ihlal ettigi ${ }^{6}{ }^{6}$ ve mültecilerin iltica ülkesinde sağlık, eğitim, çalışma hakkı gibi temel haklara erişimlerinde sıkıntı yaşandığı $\mathrm{da}^{7}$ gözlemlenmektedir. Mültecilere sağlanmak istenen koruma konusunda olduğu gibi sorumluluk paylaşımı konusunda da durumun iç açıcı olduğunu söylemek pek mümkün değildir. Dünyadaki mültecilerin \%86'sı gelişmemiş ya da gelişmekte olan ülkelerde bulunurken, 2015 yılı sonu itibariyle sadece 5 ülke tek başına dünyadaki mültecilerin \%33'üne ev sahipliği yapmaktadır. ${ }^{8} 2015$ yılında, sorumluluk paylaşımının en önemli ayağı olan üçüncü bir ülkeye yerleştirme ve yerel bütünleşme kalıcı çözümlerinden yararlanan mülteci sayısı $(139,100)$, kalıcı çözüm bekleyen mültecilerin \%1'ni dahi oluşturmamaktadır. ${ }^{9}$ Bu çalışma ise, Birleşmiş Milletler (BM) tarafından kurulan bir uluslararası rejimin ve nispeten geniş katılımlı bağlayıcı bir anlaşmanın varlığına rağmen taraf devletlerin mülteci sorununa yönelik politikalarını nasıl hâlâ bireysel davranışlarına, isteklerine ve çıarlarına göre şekillendirebildiklerini sorgulamaktadır.

Çalışma, bu araştırma sorusunun cevaplandırılabilmesi için gerekli olan Martti Koskenniemi'nin siyasi gerçeklik ve normatif düzen ikilemi, rejim kuramları ve uluslararası mülteci rejimi hakkındaki bilgileri ilk bölümde verdikten sonra ikinci bölümde, araştırma sorusunun literatürdeki yerini

1 António Guterres, "Preserving Life, Amidst Turmoil", UNHCR Global Appeal 2015 Update, s.9.

2 UNHCR, Global Trends, Forced Displacement in 2015, s.2.

3 Uluslararası mülteci rejiminin temeli, mülteci sorunuyla ilgili kurulan ilk uluslararası örgüt olan Mülteciler Yüksek Komiserliği (1921-1930) ile atılmıştır.

4 UNHCR, UNHCR concerned at reports that asylum seekers, including Syrians, denied entry to some EU countries, News Stories, 15 Kasım 2013; Helen O’Nions, Asylum-a Right Denied: A Critical Analysis of European Asylum Policy, Surrey, Ashgate Publishing, 2014.

5 International Organization for Migration, Mediterranean Migrant Deaths Reach 374; Arrivals in Greece Top 68,000 in 2016, Press Release, 5 Şubat 2016.

6 Örneğin bkz. "Mission Impossible: UNHCR says no to forced repatriation of refugees", The Express Tribune, 14 Nisan 2015; "UN: Forced Repatriation of Somalis in Dadaab Violates International Law", Hiiraan Online, 16 Nisan 2015.

7 Örneğin bkz. Human Rights Watch, Unwelcome Guests, Iran's Violations of Afghan Refugee and Migrant Rights, 20 Kasım 2013; Anna Wirth et.al., "Global Refugee Work Rights Report", Eylül 2014; Legal Report on Access to Healthcare in 12 Countries, 8 Haziran 2015.

8 Bu ülkeler sırasıyla Türkiye, Pakistan, Lübnan, İran ve Etiyopya'dır. UNHCR, Global Trends, Forced Displacement in 2015, s.2-3.

9 Ibid, s.13. 
sorgulamaktadır. Literatürün geneli mülteci sorununun günümüzde yaşadığı krizin nedenleri üzerine yoğunlaşırken, çalışma ise "nasıl” sorusunu sormaktadır. Analiz kısmına geçilen üçüncü bölümde çalışma, BM Mültecilerin Statüsüne İlişkin Sözleşme’nin ${ }^{10}$ (1951 Sözleşmesi ya da Sözleşme) devletlerin davranışlarına, isteklerine ve çıkarlarına öncelik vermelerine olanak tanıyan mülteci tanımına odaklanmaktadır. Bu bölüm, tanımın incelenmesi sırasında Birleşmiş Milletler Mülteciler Yüksek Komiserliği’nin (BMMYK) devletler için bağlayıcı olmak yerine sadece yol gösterici olan Mülteci Statüsünü Belirlemede Kullanılacak Ölçütler ve Prosedürler Üzerine El Kitabından (El Kitabı) ve devlet uygulamalarından faydalanmakta ve tanımın muğlâk ifadeler barındırmasının devletlerin dar yorumlarına imkân tanıdığını savunmaktadır.

Bir sonraki bölüm, iltica devleti tarafından mültecilere sağlanması gereken uluslararası koruma yükümlülügünü ele almakta ve 1951 Sözleşmesi'nin ilgili maddelerinden ve bu maddelerin taslak metinlerinin görüşüldüğü 2-25 Temmuz 1951 tarihinde Cenevre'de toplanan konferans tutanaklarından faydalanmaktadır. Bu bölüm; iltica hakkının Sözleşme'de hiç yer almaması, mültecilere sağlanan temel haklarla ilgili çekince koyulabilmesi ve ilgili maddelerdeki muğlâk ifadelerin varlı̆̆ neticesinde uluslararası korumanın devletler için bağlayıcı bir yükümlülük olmayabildiği sonucuna ulaşmaktadır.

Çalışmanın son bölümü ise uluslararası işbirliği ile amaçlanan sorumluluk paylaşımı mekanizmasını ele almaktadır. Bu bölüm yeniden yerleştirme ve yerel bütünleşme kalıcı çözümlerinin devletler için bağlayıcı yükümlülükler olmadığı ve giderek büyüyen mülteci sorunuyla mücadele sorumluluğunun sadece belli devletlere yüklendiği sonucuna ulaşmaktadır. Sonuç olarak çalışma, rejime taraf devletlerin mültecilere uluslararası koruma sağlanması ve sorumluluk paylaşımı konularında kurulan normatif düzene rağmen nasıl siyasi gerçeklerle hareket edebildiği sorusunu 1951 Sözleşmesi’nin yapısıyla açıklamaya çalışacaktır.

\section{Koskenniemi, Rejim Kuramları ve Uluslararası Mülteci Rejimi}

Uluslararası rejimler literatürde genel olarak, "aktörlerin beklentileri nedeniyle bir araya geldikleri belirli bir uluslararası ilişkiler alanındaki ilkeler, normlar, kurallar ve karar alma süreçleri” olarak tanımlanmaktadır. ${ }^{11}$ Genelde, bir uluslararası rejimin kurulma amacını gecçekleştirebilmesi için taraf devletlerden ortak ilkeler, normlar ve kurallar çerçevesinde işbirliği yapmaları ve bağlayıcı bir anlaşma ile ilgili konuda egemenliklerini sınırlamaları beklenmektedir. Martti Koskenniemi, uluslararası hukukun içine düştüğü ve kaçınılmaz olan yapısal bir ikilemden bahsetmektedir. Buna göre uluslararası hukuk bir yandan devletlerin davranışlarından, isteklerinden ve çıkarlarından bağımsız normatif bir düzen oluşturmak istemektedir (Utopia). Bir diğer yandan ise bu normatif düzenin sade bir doğal ahlak olarak kalmaması için devletlerin iradesi ile belirlenen somut olaylar (Apology) dikkate alınmalıdır. ${ }^{12}$ Dolayısıyla uluslararası hukuk savları siyasi gerçeklik ve normatif düzen arasında kalmaktadır. ${ }^{13}$ Uluslararası rejimlerin bünyesinde yer alan anlaşmalarda devletlerin neden ve hangi

1022 Nisan 1954'te yürürlüğe giren sözleşmeyi Nisan 2015 itibariyle 145 devlet imzalamıştır. UNHCR, States parties to the 1951 Convention relating to the Status of Refugees and the 1967 Protocol, s.1, http://www. refworld.org/docid/4ec4a7f02.html (Erişim Tarihi: 15 Mayıs 2014).

11 Stephen D. Krasner, "Structural Causes and Regime Consequences: Regimes as Intervening Variables", Stephen D. Krasner (der.), International Regimes, Ithaca, Cornell University Press, 1983, s.2.

12 Martti Koskenniemi, From Apology to Utopia: The Structure of International Legal Argument, Cambridge, Cambridge University Press, 2006, s.58, 219.

13 Ibid., s.65. 
koşullarda normatif bir düzen kurarak egemenliklerinin sınırlandırılmasını kabul ettikleri ise kuramsal olarak tartışmalara yol açmıştır.

Çıkar kavramını güç maksimizasyonu olarak tanımlayan klasik realist kurama göre devletler, anarşinin hâkim olduğu bir dünyada kendilerini dış tehditlere karşı korumalıdır. Devletler arası ilişkileri bir hayatta kalma mücadelesi olarak gören klasik realistler, devletlerin uluslararası rejimlere ancak nispi çıkarları gereği katılacaklarını savunur. ${ }^{14}$ Neoliberal kuram ise klasik realistlerin aksine devletlerin çıkarlarını sadece kendi kazançları ile tanımladıkları için işbirliğine daha yatkın olduğunu savunurlar. Bu durumda uluslararası rejimlerin, anarşinin etkilerini azaltarak işbirliği için bir zemin oluşturma ve devletlerin ilgili konuda egemenliklerini sınırlayabilme gücü vardır. ${ }^{15}$ İnşacı yaklaşım ise devletlerin politikalarını ortak norm ve değerlere göre şekillendirdiğini ve bu nedenle realist ve liberallerin aksine çıkar kavramının sabit olmadığını ve değişebileceğini savunmaktadır. Dolayısıyla inşacı yaklaşıma göre devletler sadece ortak idealler ve değerler nedeniyle bir uluslararası rejimle işbirliği yapabilir ve ilgili konuda egemenliklerini sınırlayabilir. ${ }^{16}$

Bir devletin kendi vatandaşlarına karşı ulusal koruma sağlayamaması ya da sağlamak istememesinin uluslararası toplumun ilgilenmesi gereken bir mesele olduğu anlayışının yavaş yavaş yerleşmesi, mülteci haklarının korunmasına yönelik bir rejimin de 1. Dünya Savaşı́nın ardından düzenlenmeye başlamasını beraberinde getirmiştir. Bu dönemde uluslararası mülteci rejimi, belirlenmiş özel görevleri olan geçici örgütler ${ }^{17}$ aracılığıyla devletlerin politikalarını etkilemeye ve mültecilere yardım ve kalıcı çözüm sağlamaya çalışmıştır. 2. Dünya Savaşı sonunda ise mültecilerin korunmasına ilişkin evrensel bir yasal ve örgütsel çerçeve oluşmaya başlamıştır. 3 Aralık 1949'da BM Genel Kurulu rejimin günümüzdeki örgütü olan Birleşmiş Milletler Mülteciler Yüksek Komiserliği’nin (BMMYK) 1 Ocak 1951 itibariyle kurulması kararını almıştır. ${ }^{18}$ BMMYK’nın faaliyetlerini kontrol etme görevi ise BM Genel Kurulu’nun talebi üzerine Birlemiş Milletler Ekonomik ve Sosyal Konseyi (ECOSOC) tarafından 1958 yllında kurulan Yürütme Komitesi'ndedir (ExCom). ${ }^{19}$ ExCom'un görev alanı uygulamada zamanla genişleyerek mültecilere uluslararası koruma sağlanması konusunda devletlere doğrudan tavsiyelerde bulunur hale gelmiştir. ${ }^{20}$

Uluslararası mülteci rejiminin temelini oluşturan ve rejimin ilke ve kurallarını belirleyen Sözleşme ise 1951 yılında kabul edilmiştir. Bu Sözleşme'nin hazırlanmasına iki amaç öncülük etmiştir: Birincisi, mültecilerin temel hak ve özgürlüklere sahip olabilmesi ve ikincisi, uluslararası

14 Bkz. Krasner, "Structural Causes and Regime Consequences"; Hans Morgenthau, Politics Among Nations, New York, Knopf, 2001.

15 Lisa L. Martin, "Neoliberalism", Tim Dunne et.al. (der.), International Relations Theories: Discipline and Diversity, New York, Oxford University Press, 2007, s.109-126; Jennifer Sterling-Folker, "Liberalism”, Jennifer Sterling-Folker (der.), Making Sense of International Relations Theory. Boulder, Lynne Rienner Publishers, 2006, s.55-61.

16 Alexander Wendt, "Anarchy is What States Make of it: The Social Construction of Power Politics", International Organization, Cilt 46, No.2, 1992, s.391-425; Ted Hopf, "The Promise of Constructivism in International Relations Theory", International Security, Cilt 23, No.1, 1998, s.171-200; Jonathan Mercer, "Anarchy and Identity", International Organization, Cilt 49, No.2, 1995, s.229-252.

17 Mülteciler Yüksek Komiserliği (1921-1930), Nansen Uluslararası Mülteciler Ofisi (1930-1938), Almanya'dan Gelen Mülteciler için Yüksek Komiserlik (1933-1938), Tüm Mülteciler İçin Yüksek Komiserlik (1938-1946), BM Yardım ve Rehabilitasyon İdaresi (1943-1947) ve Uluslararası Mülteci Örgütü (1947-1950).

18 BM Genel Kurulu Kararı No 319, 3 Aralık 1949.

19 Kate Jastram ve Irene Khan, "Refugee Protection: A Guide to International Refugee Law", UNHCR, s.33, http://www.unhcr.org/3d4aba564.html (Erişim Tarihi: 14 Ekim 2015).

20 Jerzy Sztucki, "The Conclusions on the International Protection of Refugees Adopted by the Executive Committee of the UNHCR Programme", International Journal of Refugee Law, Cilt 1, No.3, 1989, s.285-293. 
işbirliği sayesinde mülteci sorunuyla mücadele sorumluluğunun sadece belli devletlere yüklenmesiyle devletler arasında oluşabilecek bir gerilimin önlenmesi. ${ }^{21}$ Sözleşménin ilk amacında; mülteci haklarının korunması inşacı bir yaklaşımla ortak bir ideal olarak öngörülmekte ve taraf devletlerin, politikalarını bu ortak değer çerçevesinde şekillendireceği umulmaktadır. Sözleşme'nin ikinci amacı ise devletlerin bireysel hareket etmesindense ortak politikaların sorunların çözümünde çok daha faydalı olduğu anlayışından yola çıkmaktadır.

$\mathrm{Bu}$ amaçların Koskenniemi’nin ütopyasını yansıttığını ve Sözleşme'nin kurmak istediği normatif düzenin bir parçası olduğunu söylemek mümkündür. Bu düzende mümkün kılınmak istenen uluslararası işbirliği ve sorumluluk paylaşımı, aynı zamanda neoliberal kuramı yansıtmaktadır. Ancak Koskenniemi’nin belirttiği gibi uluslararası hukuk; devletlerin davranışları, istekleri ve çıkarları ile şekillenen siyasi gerçeklikten bağımsız olamamaktadır. ${ }^{22}$ Dolayısıyla 1951 Sözleşmesi’nin neoliberal anlayışla kurulan normatif düzen ve klasik realist anlayışın hâkim olduğu siyasi gerçeklikler arasında kalmış bir yapıya sahip olduğunu söylemek mümkündür. Sözleşme; getirdiği bağlayıcı yükümlülüklere rağmen uygulamada devletlere, mülteci sorunuyla ilgili politikalarını siyasi gerçekliklere göre şekillendirebilme imkânı sunmaktadır. Bu durum Sözleşme’de yer alan ve klasik realist kuram anlayışını yansıtan muğlâk ve göreceli ifadeler nedeniyle mümkün olmaktadır. Her ne kadar bu ifadeler hukukun değişen şartlara uyum sağlaması için gerekli olsa da, mültecilere sağlanması öngörülen uluslararası korumadaki ve devletler arasında olması öngörülen sorumluluk paylaşımındaki ${ }^{23}$ eksiklikler devletlerin bu esnekliği; yükümlülüklerini kendi davranışlarına, isteklerine ve çıkarlarına göre şekillendirmek için kullanmalarından kaynaklanmaktadır. İlgili literatür ise genel olarak, 1951 Sözleşmesi'nin öngördüğü amaçlara ulaşmada yaşadığı eksikliklerin nedenine odaklanmakta ancak bu çalışmanın amacı olan, bağlayıcı bir anlaşmanın kurduğu normatif bir düzene rağmen devletlerin nasıl hâlâ siyasi gerçekliklerine göre mülteci politikalarını şekillendirebildiklerini sorgulamamaktadır.

\section{Literatür Taraması}

Mülteci sorununun giderek büyüyen insani, siyasi ve ekonomik bir sorun olmasına ve uluslararası mülteci rejimine duyulan ihtiyacın artmasına rağmen mülteci haklarını korumak ve devletler arasında sorumluluk paylaşımı mekanizması oluşturmak mümkün olmamaktadır. Genel olarak uluslararası mülteci rejiminin yaşadığı bu krizin nedenlerini sorgulayan literatür, 3 temel neden üzerine yoğunlaşmaktadır: BMMYK'nın politikaları, rejimin uluslararası devlet sistemini koruma hedefi ve devletlerin rejimle işbirliği yapmak konusunda isteksiz olması. Literatürün bir kısmı, BMMYK’nın faaliyetlerine odaklanarak rejimin başarısızlığını açıklamaya çalışmaktadır. BMMYK’nın görev alanını ülke içinde yerinden edilenleri ve ülkelerine geri dönen mültecileri kapsayacak kadar genişletmesi ${ }^{24}$, kalıcı çözüm olarak gönüllü geri dönüşü tercih etmesi ${ }^{25}$ ve kaynak ülke faaliyetlerini arttırarak

21 UNHCR, States Parties, Önsöz.

22 Koskenniemi, From Apology to Utopia, s.18-20.

23 Yazar, mültecilerin yük olmadığı anlayışını savunduğu için yük paylaşımı yerine sorumluluk paylaşımı kavramını kullanmaktadır.

24 Gil Loescher, "The International Refugee Regime: Stretched to the Limit?", Journal of International Affairs, Cilt 47, No.2, 1994, s.351-377; Aristide R. Zolberg ve Peter M. Benda (der.), Global Migrants, Global Refugees: Problems and Solutions, Oxford, Berghahn Books, 2001.

25 Bhupinder S. Chimni, "The Geopolitics of Refugee Studies: A View from the South", Journal of Refugee Studies, Cilt 11, No.4, 1998, s.350-374; Gil Loescher, "UNHCR and the Erosion of Refugee Protection", Forced Migration Review, No.10, 2001, s.28-30. 
önleyici bir politika izlemesinin devletlerin istismarına imkân vermesi ${ }^{26}$ yaşanan sorunları açıllamak için kullanılmaktadır. Bir kısım literatür ise uluslararası mülteci rejiminin mülteci haklarından çok uluslararası devlet sistemini koruduğunu savunmaktadır. ${ }^{27}$ Mültecilerin kendi devletlerinin korumasından yararlanamaması devlet-birey ilişkisine zarar vermekte ve aslında rejim, mültecilerin haklarını korumak yerine bu aykırılığı düzelterek devletler sistemini korumayı amaçlamaktadır. Son olarak ise bir kısım literatür; devletlerin iltica hakkını tanımak istememelerini, giderek artan sınırlayıcı politikalarını ve ülkelerinde bulunan mültecilerin temel haklara erişimini engelleme eğilimlerini devletlerin rejimle işbirliği yapma konusundaki isteksizlikleriyle açıllamaktadır. ${ }^{28}$

$\mathrm{Bu}$ çalışma da mülteci haklarının korunmaması ve sorumluluk paylaşımı mekanizmasının işlememesinin temel nedeninin devletlerin isteksizliği olduğunu savunmaktadır. Ancak bu konudaki literatür genel olarak devletlerin isteksizliğinin sebebine odaklanmakta ve devletlerin güvenlik kaygıların ${ }^{29}$ ve artan mülteci sayısını ${ }^{30}$ devletlerin isteksizliğinin temel sebepleri olarak göstermektedir. $\mathrm{Bu}$ çalışma ise devletlerin isteksizliğinin nedeni yerine, uluslararası bir rejimin ve bağlayıcı bir anlaşmanın varlığına rağmen taraf devletlerin mülteci sorununa ilişkin politikalarını nasıl hâlâ bireysel devletler olarak şekillendirebildiklerini sorgulamakta ve Sözleşme’nin yapısının ilgili konularda taraf devletlerin egemenliklerini sınırlamadığını savunmaktadır. Bu durumun temel unsurlarından birisi ise dar yoruma imkân veren mülteci tanımıdır.

\section{Mülteci Tanımı ve Dar Yorum İmkânı}

İltica başvurusunda bulunan kişi (asylum seeker), bir devlete uluslararası koruma talebiyle başvurmuş ancak mülteci statüsü talebi henüz inceleme aşamasında olup hakkında olumlu ya da olumsuz bir karar verilmemiş kişidir. Koruma sorumluluğunun bir parçası olarak iltica başvurusunda bulunan kişilerin mülteci olup olmadığını tespit etme yükümlülüğü ise ilgili iltica devletine aittir. ${ }^{31} 1951$ Sözleşmesi'ne göre “1 Ocak 1951'den önce meydana gelen olaylar sonucunda ırkı, dini, tabiiyeti, belli bir toplumsal gruba mensubiyeti veya siyasi düşünceleri yüzünden, zulme uğrayacağından haklı sebeplerle korktuğu için vatandaşı olduğu ülkenin dışında bulunan ve bu ülkenin korumasından yararlanamayan, ya da söz konusu korku nedeniyle, yararlanmak istemeyen; yahut tabiiyeti yoksa ve bu tür olaylar sonucu önceden yaşadığı ikamet ülkesinin dışında bulunan, oraya dönemeyen veya söz konusu korku nedeniyle dönmek istemeyen her şahıs" mültecidir. ${ }^{32}$ 1951 tanımında yer alan zaman sınırlaması nedeniyle, zamanla Sözleşme kapsamına girmeyen

26 Michael Barutciski, "The Reinforcement of Non-Admission Policies and the Subversion of UNHCR: Displacement and Internal Assistance in Bosnia-Herzegovina (1992-94)", International Journal of Refugee Law, Cilt 8, No.1/2, 1996, s.49-110; Bill Frelick, "Preventive Protection and the Right to Seek Asylum: A Preliminary Look at Bosnia and Croatia”, International Journal of Refugee Law, Cilt 4, No.4, 1992, s.439-454.

27 Dennis Gallagher, "Durable Solutions in a New Political Era”, Journal of International Affairs, Cilt 47, No.2, 1994, s.429-50; Charles B. Keely, "How Nation-States Create and Respond to Refugee Flows", International Migration Review, Cilt 30, No.4, 1996, s.1046-1066.

28 Tanya Basok, "Refugee Policy: Globalization, Radical Challenge, or State Control?", Studies in Political Economy, No.50, 1996, s.133-166; Adam Roberts, "More Refugees, Less Asylum: A Regime in Transformation", Journal of Refugee Studies, Cilt 2, No.4, 1998, s.375-395.

29 Alexander Betts, Forced Migration and Global Politics, West Sussex, Wiley-Blackwell, 2009; Matthew J. Gibney, "Security and the Ethics of Asylum after 11 September", Forced Migration Review, No.3, 2002, s.40-43.

30 Roberts, "More Refugees, Less Asylum"; Astri Suhrke, "Burden-sharing during Refugee Emergencies: The Logic of Collective versus National Action", Journal of Refugee Studies Cilt 11, No.4, 1998, s.396-415.

31 UNHCR, Advisory Opinion on the Extraterritorial Application of Non-Refoulement under the 1951 Convention, s.2.

321951 Sözleşmesi, Md.1(A/2). 
yeni mülteci durumları ortaya çıkmış ve Sözleşme'de yapılan yegâne değişiklik olan 1967 tarihli Protokol zaman sınırlamasını ortadan kaldırmıştır. ${ }^{33}$ Sözleşme, zaman sınırlamasının yanı sıra coğrafi sınırlama imkânını da getirmiştir. Sözleşme imzalanırken devletlerden "1 Ocak 1951'den önce meydana gelen olaylar” ifadesinden "1 Ocak 1951'den önce Avrupa'da meydana gelen olaylar” mı yoksa "1 Ocak 1951'den önce Avrupa'da veya başka bir yerde meydana gelen olaylar” anlamını mı kabul ettiklerini belirtmeleri istenmiştir. ${ }^{34}$ Zaman sınırlamasının aksine coğrafi sınırlama hakkı, 1967 Protokolü'nde de korunmuştur. ${ }^{35}$

1951 Sözleşmesi uyarınca kimin mülteci statüsü alacağına iltica başvurusu yapılan devlet karar verdiği için, Sözleşme tanımında -değişen şartlara uyum sağlaması için bile olsa- farklı yorumlara imkân veren muğlâk ifadelerin yer almaması beklenebilir. Ancak tanımda geçen "zulüm”, "haklı sebep" ve belli bir sosyal gruba aidiyet” kavramları net olarak tanımlanmayarak, devletlerin tanımı dar bir şekilde yorumlamaları mümkün kılınmıştır. Ayrıca Sözleşme’nin 1. maddesinde mülteci statüsü alamayacak kişiler de belirtilmiş, "ciddi kanaat" ve "ağır bir genel suç" ifadeleri ile dar yoruma yine imkân tanınmıştır.

\section{Zulüm mü, Değil mi?}

Tanımda geçen zulüm kavramı 1951 Sözleşmesi’nde muğlâk olarak bırakılmıştır. Ergüven ve Özturanlı'ya göre bu durum bilinçli olup, kavramın geniş yorumuna imkân sağlamak ve böylelikle yeni zulüm çeşitlerinin zamanla yükleneceği yeni anlamlarla Sözleşme kapsamı dışı kalmasının önlenmesi amaçlanmıştır. ${ }^{36}$ Zulüm kavramının net olarak tanımlanmamasının mülteci tanımının değişen koşullara uyarlanabilmesi için geniş yorum imkânı bıraktığı kabul edilse dahi, bu durumun arzu eden devletlere dar yorum imkânı sağladığı da göz ardı edilemez. Bir başka deyişle taraf devletlerin, klasik realist kuramın savunduğu üzere, mülteci tanımındaki zulüm kavramı ile ilgili bağlayıcı net bir yükümlülük altına girmeyerek egemenliklerini sınırlamaktan kaçındıklarını söylemek mümkündür.

Zulüm kavramının yanı sıra, tartışılan bir başka konu ise zulme kimin sebep olduğunun önemli olup olmadığıdır. Tanımın yapıldığı dönemde zaman sınırlaması bakımından tanım kapsamına giren kişiler yoğunlukla Nazi rejiminden kaçan kişiler olduğu için Koser, tanımda zulmü gerçekleştiren merci olarak devletin kastedildiğini belirtmektedir. ${ }^{37}$ Ancak zulüm aynı zamanda genel güvensizlik ortamlarında milisler, terör örgütleri, ayrılıkçı gruplar, etnik ya da dini açıdan çoğunlukta olan gruplar gibi devlet dışı aktörler tarafından da kaynaklanabilmektedir. BMMYK da iltica başvurusunda bulunan kişinin doğrudan kendisine yönelik bir zulüm yerine ülkesindeki genel güvensizlik ortamından kaynaklı zulüm görmesinin de mülteci olarak tanınmasına neden olabileceğini belirtmektedir. ${ }^{38}$ Ancak böyle bir durumun zulüm olarak tanımlanabilmesi için bu duruma devlet yetkililerinin bilinçli bir şekilde göz yumması, zulme uğrayan kişiyi etkin bir şekilde korumayı reddetmesi ya da bu kişiyi koruma gücünün olmaması gerekmektedir. ${ }^{39}$

33 UNHCR, States parties, 1967 Protokolü, Md.1(2).

341951 Sözleşmesi, Md.1(B/1).

351967 Protokolü, Md.1(3).

36 Nasıh S. Ergüven ve Beyza Özturanl1, "Uluslararası Mülteci Hukuku ve Türkiye”, $A \ddot{U H D F}$, Cilt 62, No.4, 2013, s.1022.

37 Khalid Koser, International Migration A Very Short Introduction”, Oxford, Oxford University Press, 2007, s.71.

38 UNHCR, Handbook, para.52.

39 Ibid., para. 65 
El kitabının açıklamalarıyla bu tartışma netlik kazanmış gibi görünse de, el kitabının devletler için bağlayıcı olmadığını ve iltica devletinin zulmün kaynağı ile ilgili dar yorum imkânını barındırmaya devam ettiği söylenebilir. Aslında uygulamada devletlerin, devlet dişı aktörler tarafından yapılan zulme göz yumdukları ya da engel olmadıkları zaman bu zulme maruz kalan kişilerin halen 1951 Sözleşmesi kapsamında olabilecekleri konusunda bir uzlaşı olduğunu söylemek mümkündür. Uygulamada ayrılıkların bulunduğu asıl nokta ise devletlerin, devlet dışı aktörler tarafından yapılan bir zulme engel olma gücüne sahip olmadıkları zaman ortaya çıkmaktadır. ${ }^{40}$ Örneğin Almanya, Fransa, İsviçre ve İtalya gibi bazı devletler zayıf devletlerin ülkelerindeki zulme engel olamamasını 1951 Sözleşmesi kapsamında görmeyen ve devletin her halükarda devam eden sorumluluğunu öne çıartan mesuliyetçi görüşü (accountability view) savunmaktadır. ${ }^{41}$ Hollanda, Avustralya ve İngiltere gibi bazı devletler ise BMMYK'nın de benimsemiş olduğu, 1951 Sözleşmesi'nin amacı olan uluslararası koruma anlayışının zayıf devletlerde de geçerli olması gerektiğini savunan korumacı görüşü (protection view) benimsemektedir. ${ }^{42}$

\section{Haklı Korku}

Zulüm unsurunun yanı sıra, tanımda yer alan “zulme uğrayacağından haklı sebeplerle korkmak” ifadesi de yoruma açık olup taraf devletlerin egemenliklerini sınırlamak istememe anlayışını yansıtmaktadır. Korkunun haklı sebeplere dayanması hem nesnel hem de öznel unsur içermektedir ve el kitabına göre değerlendirmede her iki unsur da dikkate alınmalıdır. ${ }^{43}$ Başvuran kişinin beyanını içeren öznel unsur kısmında konu hakkındakigerçekleryeterince açık değilsekişinin inandırıcılı̆ğ değerlendirilmektedir. ${ }^{44}$ Nesnel unsur kısmında ise zulme uğrayacağından haklı sebeplerle korkmak unsurunun varlığı nesnel olarak da tespit edilmelidir. ${ }^{45} \mathrm{Bu}$ durumda kişinin durumu tasviri kadar kaynak ülkenin koşullarının anlaşılması da yol gösterici olmaktadır. ${ }^{46}$ Devletlerin öznel unsura yeterince önem vermemesi kaygısı yaşayan BMMYK, bir mültecinin hikâyesinin her noktasını kanıtlamasının neredeyse imkânsız olduğunu ve devletlerin böyle bir beklentiye girmesi halinde mültecilerin büyük çoğunluğunun statüsünün tanınmayacağını belirtmektedir. ${ }^{47}$

Örneğin, Hazara etnik kökenli ve Şii mezhebine mensup Afganistan vatandaşı A, 2001 yılı başında Avustralya' ya ulaşmış ve etnik kökeni ve mezhebi nedeniyle Taliban kontrolündeki Afganistan'a geri dönmesi halinde hayatından endişe ettiğini belirterek iltica başvurusunda bulunmuştur. ${ }^{48}$ Başvuruyu değerlendiren ilgili bakanlık, A’nın Afganistan vatandaşı olduğuna ikna olmadığı için başvurusunu reddetmiştir. A, karara yargı yoluyla itiraz etmiş; sonuç değişmeyince temyize gitmiş ve nihayet bir buçuk yıl sonra mahkemeyi Afganistan vatandaşı olduğuna ikna etmiştir. Aradan geçen zamanda ise Afganistan’a Amerika Birleşik Devletleri (ABD) müdahalesi gerçekleşmiş ve Taliban

40 Walter Kälin, "Non-state Agents of Persecution and the Inability of the State to Protect", Geo. Immigr. LJ, No.15, 2000, s.416.

41 Andrew I. Schoenholtz, "New Refugees and the Old Treaty: Persecutors and Persecuted in the Twenty-First Century", Chicago Journal of International Law, Cilt 16, No.1, 2015, s.101.

42 Roland H. M. Bruin, "Working Party on Non-State Agents of Persecution: 2002 Report", 5th IARLJ Conference, Yeni Zelanda, 2002, s.452-53.

43 UNHCR, Handbook, para.38.

44 Ibid., para.41.

45 Ibid., para. 38.

46 Ibid., para. 42.

47 UNHCR, Handbook, para.203.

48 SGDB v. Minister for Immigration \& Multicultural \& Indigenous Affairs, 15 March 2004, S 590 OF 2003, para.2. 
rejimi ülkedeki kontrolü kaybetmiştir. ${ }^{49} \mathrm{Bu}$ durumda mahkeme, nesnel unsurun yokluğuna karar vermiş ve A’nın Afganistan'da Hazaraların yoğun olarak yaşadığı ve evinin olduğu bölgede güvende olacağına ikna olmuştur. ${ }^{50}$ Ancak öznel unsur açısından bakıldığında A’nın söylemi, kendi bölgesine gidebilmek için Peştun bölgelerinden geçmesi gerektiği ve Afganistan’a geri gönderilmesi durumunda evine varamama korkusu taşıdığı yönünde olmuştur. ${ }^{51}$ Nihayetinde mahkeme, duyulan bu korkunun nesnel unsur dikkate alındığında haklı bir dayanağı olmadığına karar vermiş ve iltica başvurusunu reddetmiştir. ${ }^{52}$

A, öznel unsuryeterince dikkate alınmadığıve anlattıklarının doğruluğu yeterince araştırılmadığı gerekçesiyle 2004 yılında bir üst mahkemeye başvurmuştur. Üst mahkeme, süreçte eksiklikler olduğunu ve değerlendirme sürecinin yeniden başlaması gerektiğine karar vererek dosyayı ilgili mahkemeye iade etmiştir. ${ }^{53}$ Bir başka deyişle A, korkusunun haklı bir sebebe dayanıp dayanmadığının adil bir şekilde değerlendirilmesi için yıllar süren bir hukuk mücadelesi vermek zorunda kalmıştır. Geçen bu yıllar içinde ise A, 1951 Sözleşmesi’nden kaynaklı mülteci haklarından yoksun bir şekilde idari gözetim altında tutulmuştur.

\section{Cinsiyet ve Cinsel Kimlik Kaynaklı Zulüm}

1951 tanımıyla ilgili yorumlanma ihtiyacı duyulan bir diğer unsur ise tanımda yer alan zulüm sebeplerinin cinsiyet ve cinsel kimliği kapsayıp kapsamadığıdır. 1951 Sözleşmesi cinsiyet ve cinsel kimliği zulüm unsurları arasında açıkça tanımlamamaktadır. Ancak cinsel şiddet, aile içi şiddet, mecburi aile planlaması, kadın sünneti ve cinsel kimlik kaynaklı zulüm; yaşadığımız dünyanın bir gerçeğidir. Cinsiyet ve cinsel kimlik unsurunun tanımda açıkça yer almaması mültecilerin uzun süren hukuki mücadeleler vermelerine ve bazen de mülteci olarak kabul edilmemelerine neden olabilmektedir. ${ }^{54}$

Örneğin Pakistan vatandaşı B, eşi tarafından evden kovulmuş ve İngiltere'ye gitmiştir. Kısa bir süre sonra da doğum yapmıştır. Eşinin kendisini zina yapmakla suçlayacağından korktuğu için 1993 yılında İngiltere'de iltica başvurusunda bulunmuştur. B'nin zulme uğrayacağından duyduğu korkunun haklı olup olmadığını araştırma gereği duymayan ilgili bakanlık, kadınların 1951 Sözleşmesi tanımında geçen belli bir sosyal gruba ait olmadığı gerekçesiyle başvuruyu reddetmiştir. ${ }^{55}$

Bir başka örnekte ise ilk kararda olmasa da yapılan itiraz sonucu BMMYK’nın savunduğu gibi kapsayıcı bir yorum yapılmıştır. 19 yaşındaki Togo vatandaşı $\mathrm{D}$, normalde kız çocuklarının 15 yaşına geldiklerinde sünnet edildikleri bir kabilenin mensubudur. Kabile içinde nüfuzlu bir insan olan babası koruduğu için D sünnet edilmemiştir. Ancak D’nin babası bir yıl sonra vefat etmiş, ailenin başına geçen halası ise D’yi 45 yaşında ve 3 hanımı olan bir adamla zorla evlendirmek istemiştir. Halası ve müstakbel eşi düğün merasiminden önce sünnet işleminin gerçekleştirilmesini planlamıştır. Ablasının yardımıyla Togo'dan kaçan D, sahte bir pasaportla ABD'ye ulaşmış ve havaalanında iltica başvurusunda bulunmuştur. ${ }^{56}$ Başvurusu reddedilen ve sınır dışı edilecek olan D'nin itirazı sonucu dosyayı ele alan

49 Ibid., para.3.

50 Ibid., para.7.

51 Ibid., para.8.

52 Ibid., para.9.

53 Ibid., para.28.

54 UNHCR, Handbook, para.77.

55 Islam v. Secretary of State for the Home Department; R v. Immigration Appeal Tribunal and Another, ex parte Shah, 25 March 1999.

56 In re Fauziya KASINGA, Applicant File A73 476 695, 13 Haziran 1996, Interim Decision No 3278, s.358-359. 
mahkeme, uygulanan sünnetin haklı korkuya dayanan bir zulüm olduğuna ve bu zulmün belli bir sosyal gruba mensubiyetten kaynaklandığına karar vermiş ve D’nin mülteci statüsünü onaylamıştır. ${ }^{57}$

Görüldüğü üzere, tanımda açıkça yer almaması nedeniyle taraf devletlerin bu konuda kapsayıcı yorum kadar sınırlayıcı yorum yapabilmesi de mümkün olmaktadır. Tanımda açıç̧a yer verilmemesi nedeniyle, cinsiyetin yanı sıra cinsel kimlik konusunda da sıkıntılar yaşanabilmektedir. Örneğin, homoseksüel olduğu için zulümden korkan İran vatandaşı E, 1992 yılında Yeni Zelanda'ya uluslararası koruma başvurusunda bulunmuş ancak başvurusunun değerlendirilmesi ve mahkeme tarafindan homoseksüellerin belli bir sosyal grup oluşturduğuna karar verebilmesi için E'nin 3 yıl beklemesi gerekmiştir. $^{58}$

\section{Mülteci Statüsü Alamayacak Kişiler}

Mülteci tanımının yapıldığı 1. maddede, mülteci statüsü alamayacak kişileri tanımlanmaktadır. Buna göre uluslararası belgelerde tanımlandığı şekilde barışa karşı bir suç, bir savaş suçu ya da insanlığa karşı bir suç işlediği; iltica ülkesi dışında ağır bir genel suç işlediği ya da BM ilkelerine ve amaçlarına aykırı fiillerden suçlu olduğu konusunda "ciddi kanaat” bulunan kişiler için Sözleşme hükümleri uygulanmamaktadır. ${ }^{59}$ Örneğin Ruanda vatandaşı F, 1993 yılında Kanada'ya iltica başvurusunda bulunmuş ancak başvurusu aşırı uç bir Hutu siyasi partisinin aktif üyesiyken savaşın sona ermesi için yapılan müzakereler aleyhinde bir konuşma yaptığı ve dolayısıyla insanlığa karşı suç işlediği gerekçesiyle reddedilmiştir. ${ }^{60}$

$\mathrm{Bu}$ maddede tartışmalı olan ifadelerden biri "ciddi kanaat" ifadesidir. Devletler mülteci statüsü vereceği kişileri ağır bir genel suç işlediği ya da BM ilke ve amaçlarına aykırı bir fiilden dolayı suçlu olduğu konusunda suçu kanıtlanmadan "ciddi kanaat” nedeniyle Sözleşme kapsamı dışında değerlendirebilmektedir. Bu muğlâk ve göreceli ifade klasik realist kuramın savunduğu gibi taraf devletlere gerektiğinde kendilerini dış tehditlere karşı koruma alanı yaratmaktadır. Bu maddede tartışmalı olan ifadelerden bir diğeri ise "ağır bir genel suç" ifadesidir. Örneğin Cezayir vatandaşı G, İngiltere'ye yasadışı yollardan girmiş ve Cezayir'e dönmesi halinde siyasi görüşleri dolayısıyla hayatının ya da özgürlüğünün tehdit altında olduğunu belirterek iltica başvurusunda bulunmuştur. İngiltere, başvuruyu G’nin Cezayir'de yasadışı bir siyasi örgüte üye olması ve sivillerin öldüğü patlamaların planlanmasında rol oynaması gerekçesiyle reddetmiştir. G’nin siyasi suçlu olduğu iddiasıyla yaptığı itiraz da, masum insanların ölümüne yol açan bombalı eylemlerin siyasi suç sayılamayacağı yönünde bir kararla reddedilmiştir. ${ }^{61}$

Özetle, 1951 Sözleşmesi’nin 1. maddesi içerdiği muğlâk ifadeler nedeniyle mülteci statüsünün belirlenmesi ve mülteci statüsü alamayacak kişiler konusunda taraf devletlere kararlarını kendi davranışlarına, isteklerine ve çıkarlarına göre şekillendirme imkânı sunmaktadır. Mülteci tanımının yanı sıra, uluslararası mülteci rejiminin temelini oluşturan ve amaçladığı normatif düzenle neoliberal kuramı yansıtan mültecilere uluslararası koruma sağlanması konusunda da 1951 Sözleşmesi’nin klasik realist kuramı haklı çıkardığı görülmektedir. Nitekim geri göndermeme ilkesinin ihlal edilmesi,

57 Ibid., s.368.

58 Refugee Appeal No. 1312/93, Re GJ, No 1312/93. Benzer bir durum için bkz. Geovanni Hernandez-Montiel v. Immigration and Naturalization Service, United States Court of Appeals for the Ninth Circuit, 24 Ağustos 2000, A72-994-275.

591951 Sözleşmesi, Md.1(f).

60 Mugesera v. Canada, 28 Haziran 2005, 2005 SCC 40.

61 T v. Secretary of State for the Home Department, 22 May1s 1996, 2 All ER 865. 
mültecilerin iltica hakkını kullanmalarının engellenmesi ve sağlık, çalışma ve eğitim gibi temel haklara erişim konusunda sıkıntılar yaşanması; ne yazık ki çoğu zaman, devletlerin 1951 Sözleşmesi’nden kaynaklı yükümlülüklerini ihlal ettikleri anlamına gelmeyebilir.

\section{Uluslararası Koruma}

Bir devletin asli görevi vatandaşlarının güvenliğini sağlamaktır. Mülteci ise belirli nedenlerden dolayı devletinin ulusal korumasından yararlanamadığı ya da yararlanmak istemediği için uluslararası toplum tarafından korunması gerektiğine karar verilen kişidir. Mültecilerin uluslararası korunması temel olarak mültecinin maddi ve idari olarak koruma ve yardım almasıyla garanti altına alınmasıdır. 1951 Sözleşmesi iltica hakkına yer vermemekle birlikte mültecilere uluslararası koruma sağlanması ile ilgili cezalandırmama, ${ }^{62}$ ayrımcılık yapmama ${ }^{63}$ ve geri göndermeme ilkelerini kapsamakta ve mültecilerin ilgili iltica devletinde temel haklara erişimini düzenlemektedir. Çalışma bu bölümde geri göndermeme ilkesini, iltica hakkı tartışmasını ve temel haklara erişimi inceleyecek olup cezalandırmama ve ayrımcılık yapmama ilkelerini kapsamı gereği ele almayacaktır.

\section{Geri Göndermeme IIlkesi}

Mültecilere uluslararası koruma sağlanmasında oldukça önemli bir yere sahip olan geri göndermeme ilkesine göre mülteciler ırkı, dini, tabiiyeti, belli bir toplumsal gruba mensubiyeti veya siyasi düşünceleri nedeniyle hayatlarının veya özgürlüklerinin tehdit altında olacağı bir ülkeye iade edilemez veya geri gönderilemez. ${ }^{64} 1951$ Sözleşmesi’nde güvence altına alınan bu ilke aynı zamanda uluslararası örf ve âdet hukuku kuralı haline gelmiştir. ${ }^{65}$

Ancak 1951 Sözleşmesi, geri göndermeme ilkesine de dar yoruma müsait muğlâk ifadelerden oluşan istisnai bir hüküm eklenmiştir. Madde 33(2)'ye göre geri göndermeme ilkesi, bulunduğu ülkenin güvenliğine tehdit teşkil ettiğine dair ciddi sebepler bulunan veya ağır bir genel suçtan dolayı kesinleşmiş bir hükümle mahkûm olduğu için söz konusu ülkenin halkı açısından bir tehlike oluşturmaya devam eden bir mülteci için uygulanmamaktadır. Ayrıca Sözleşme'nin 32(1) maddesi devletlere, ulusal güvenlik ya da kamu düzeni gerekçesiyle ülkelerinde yasal olarak bulunan mültecileri sınır dışı etme hakkı vermektedir. ${ }^{66}$

Madde 32(1)'in devletlere ulusal güvenlik ve kamu düzeni gerekçeleriyle mültecileri sınır dışı etme hakkı tanıması, Sözleşme’nin taslak metni üzerinde yapılan konferansta da eleştirilere yol açmıştır. Görüşmelere gözlemci olarak katılan hükümet dışı örgütlerden biri olan Caritas Internationalis temsilcisine göre, bu madde mülteciyi, sınır dışı edilme kararı sonrası o ülkede yasadışı şekilde kalmak ve ölüm riski taşıdığı kendi ülkesine dönmek arasında tercih yapmaya zorlayacaktır. ${ }^{67} \mathrm{ABD}$ de kamu düzeni kavramının muğlâk ve çok geniş olmasından duyduğu kaygıyı dile getirmiş, bu maddenin

62 Sınırlayıcı göç politikaları, sığınma arayışında olan kişilerin devletlerin göç yasalarını ihlal etmelerini gerektirebilir. Ancak Sözleşme'nin 31. maddesine göre taraf devletler, iltica başvurusu yapmak için yasadışı yollarla ülkelerine giren veya ülkelerinde yasadışı bir şekilde kalan kişileri cezalandırmamakla yükümlüdür.

63 Sözleşme'nin 3. maddesinde belirtilen ayrımcıllk yapmama ilkesi uyarınca taraf devletler; Sözleşme hükümlerini ırk, din ya da kaynak ülke farkı gözetmeden uygulamalıdır.

641951 Sözleşmesi, Md.33.

65 UNHCR, The Principle of Non-Refoulement as a Norm of Customary International Law, para.1.

66 Ibid., Md.32.

67 Tam Yetkili Temsilciler Konferans1, 15. Toplant1, 23 Kasım 1951, A/CONF.2/SR.15. 
mümkün olduğunca sınırlayıcı yorumlandığı aşırı istisnai durumlarda bile kişinin ölüme veya zulme gönderilmesi anlamına gelebileceğini belirtmiştir. ${ }^{68}$

Görüşmeler sırasında bazı devletler ise ilgili maddelerin görüşmeleri sırasında iltica hakkından kaynaklı olası suiistimaller için kendilerini korumak zorunda olduklarını belirtmiştir. ${ }^{69}$ Örneğin İngiltere, devletlerin sınır dışı kararıyla mültecinin göreceği olası zarar ve kalması halinde kamu güvenliği için oluşacak tehdit arasında karar verme yetkisinin devletlere bırakılması gerektiğini savunmuştur. ${ }^{70}$ Fransa da, mültecinin ev sahibi ülkede oturma izni olmasına ve kısmen de olsa toplumda bir yer bulmasına rağmen bir mülteciyi gerektiğinde sınır dışı etme hakkını elinde tutmak istediğini belirtmiştir. ${ }^{71}$ Madde 33(2)'de geçen ve durumu yorumlama yetkisini öznel bir şekilde devletlere bırakan “ciddi sebepler” ifadesi de İngiltere'nin talebi üzerine eklenmiştir. İngiltere, ifadenin eklenme talebinin sebebini açıklarken bir mültecinin ulusal güvenliğe tehdit teşkil edip etmediğine devletin kendisinin karar vermesi gerektiğini belirtmiştir. ${ }^{72}$ BMMYK ise Madde 33(2)'nin istisnai hükmü hakkında kendisinden istenen uzman görüşünde, bir sebebin "ciddi” olabilmesi için güvenilir ve inandırıcı kanıtlarla desteklenmesi gerektiğini ve her ulusal güvenlik sorununun bu istisnai hükmün işletilmesi için bir dayanak oluşturmayacağını belirtmiştir. Ayrıca uluslararası insan hakları anlaşmalarındaki istisnai hükümlerin sınırlayıcı yorumlanması gerektiğinin bir genel hukuk kuralı olduğunu hatırlatmıştır. ${ }^{73}$ Ancak istisnai hükümlerle ilgili arzu edilen sınırlayıcı yoruma rağmen, görüşme tutanaklarının incelenmesi Madde 32(1) ve 33(2)'de yer alan ifadelerden kaygı duyan ve bu ifadeleri destekleyen katılımcıların benzer nedenlere sahip olduğunu göstermektedir. Kaygı duyanlar, geniş bir yorum sonucu mültecilere sağlanan uluslararası korumanın azalacağından endişe ederken; destekleyen devletler de bu endişeyi haklı çıkarırcasına, gerektiğinde mültecilere sağlanan korumayı azaltabilme yetkisi istemektedir. Bu durum Sözleşmede, mülteciyi sınır dışı etme ve geri göndermeme ilkesine istisnai hükümler getirilme nedeninin klasik realist kuramın öngördüğü gibi devletlerin kendilerini dış tehditlerden korumak olduğu iddiasını destekler niteliktedir.

\section{IItica Hakkı Tartışması}

İltica hakkı, zulüm karşısında başka devletlere sığınma talebinde bulunma ve sığınma olanağından yararlanma hakkıdır. Ancak bu hakkın devletlere mi yoksa korunmaya ihtiyaç duyan kişiye mi tanındığı tartışmalıdır. Bu durumun nedeni 1951 Sözleşmesi’nin taraf devletlerin sığınma başvurularını değerlendirme süreçleriyle ilgili bir hüküm içermemesidir. Bir başka deyişle iltica, devletlerin eğer isterlerse sağlayacakları bir koruma kurumudur ve iltica başvurusunu kabul edip etmemek egemenlik hakları dâhilindedir. ${ }^{74}$ Ayrıca devletler hemen her zaman, bu hakkın kullanılabilmesi için kişinin ülke sınırlarından içeriye girmiş olması şartını koşmaktadırlar. Nitekim, iltica hakkının diplomatik temsilciliklerde kullanılması pek kabul gören bir uygulama değildir. ${ }^{75} \mathrm{Bu}$ durum, mültecilerin iltica

68 BM Mülteciler ve Vatansız Kişiler Geçici Komitesi, 40. Toplantı, Özet Tutanakları, 22 Ağustos 1950, E/AC.32/ SR.40.

69 Tam Yetkili Temsilciler Konferans1, 16. Toplant1, 23 Kasım 1951, A/CONF.2/SR.16.

70 Ibid.

71 Tam Yetkili Temsilciler Konferans1, 29. Toplant1, 28 Kasım 1951, A/CONF.2/SR.29.

72 Ibid.

73 UNHCR, Re: Request for Advisory Opinion, 6 Ocak 2006, s.3, 4, 6 http://www.refworld.org/pdfid/43de2da94. pdf (Erişim Tarihi: 18 Haziran 2016).

74 María-Teresa Gil-Bazo, “Asylum as a General Principle of International Law”, International Journal of Refugee Law, Cilt 27, No.1, 2015, s.7.

75 Bkz. Gregor Noll, "Seeking Asylum at Embassies: A Right to Entry under International Law?", International Journal of Refugee Law, Cilt 17, No.3, 2005, s.542-573. 
hakkını kullanabilmek için göçmen kaçakçıları aracılığıyla oldukça zorlu ve tehlikeli yollardan sınırları geçmeye çalışmalarına sebep olmaktadır.

Bağlayıcılığı olmayan 1948 tarihli İnsan Hakları Evrensel Beyannamesi 14. Maddesi iltica hakkını temel bir insan hakkı olarak tanısa da, iltica hakkına 1951 Sözleşmesi’nde yer verilmemesi nedeniyle ülke sınırlarından içeriye girmek için gerekli izinleri olmayan ancak iltica hakkından faydalanmak istediğini söyleyen bir kişinin sınırdan içeriye alınması gerekip gerekmediği konusu oldukça tartışmalıdır. İltica hakkının 1951 Sözleşmesi’nde açıkça yer almamasının nedeninin, uluslararası mülteci hukukunun bireylerin korunması ve devletlerine kabul etmeye isteyeceği taahhütler arasında bir denge kurma çabası olduğunu söylemek mümkündür. ${ }^{76}$ Nitekim Sözleşme’nin taslak metninin görüşüldügü konferans tutanakları da bu kanaati destekler niteliktedir. Görüşmeler sırasında Fransa, mevcut Sözleşme metninin bir devletin iltica hakkını reddedebileceğini kabul ettiğini belirtmiştir. Fransa'ya göre bunun zaten böyle olması gerekmektedir çünkü bir devletin tam olarak kontrol edemediği kişilere karşı koşulsuz bir yükümlülüğe imza atması mümkün değildir. ${ }^{77}$

Öte yandan, bir başka bakış açısı ile devletlerin iltica hakkını tanıma yükümlülüğü olduğu yorumunda bulunmak da mümkündür. Daha önce belirtildiği üzere kişi, 1951 Sözleşmesi'nin mülteci tanımı kriterlerine uyduğu sürece mültecidir ve mülteci statüsüne karar verme işlemi doğası gereği sadece açıklayıcı bir işlemdir. Bir başka deyişle bir kişi statüsü tanındığı için mülteci olmaz, mülteci olduğu için statüsü tanınır. ${ }^{78} \mathrm{Bu}$ durumda geri göndermeme ilkesi, devletin sınırının gerisinde başlamakta ve bu ilkenin henüz devlet ülkesine gelip iltica başvurusunda bulunmamış mülteciler dâhil bütün mültecilere uygulanması gerekmektedir.

Ancak mültecileri sınırda reddetmenin yasaklandığına yönelik yekpare bir devlet kabulü ve uygulaması yoktur. ${ }^{79}$ Örneğin ABD Yüce Mahkemesi, geri göndermeme ilkesinin ülke dışı etkisi olup olmadığını incelemiş ve ülkeye henüz giriş yapmamış ancak iltica başvurusunda bulunmak isteyen kişileri sınırda reddetmenin, bir başka deyişle iltica hakkını engellemenin, bu ilkenin ihlali anlamına gelmediğini belirtmiştir. ${ }^{80}$ Avrupa Konseyi İnsan Hakları Komiserliği ise Suriye vatandaşlarının Avrupa ülkelerince sınırlardan içeriye alınmamasının geri göndermeme ilkesinin ihlali olduğunu belirtmiştir. ${ }^{81}$ Ancak bu konuda Almanya ve Avusturya gibi ilgili devletler, farklı yaklaşımlarla geri göndermeme ilkesini ihlal etmediklerini savunmaktadır. Örneğin, sınır kavramının Schengen bölgesinin dış sınırlarını ifade ettiği, dolayısıyla üye devletler arasındaki iç sınırlarda iltica başvurusu almayı reddetmenin iltica hakkını engellemediği iddia edilmektedir. Bir diğer yaklaşım ise iltica başvurusu yapmak isteyen kişinin Avrupa Birliği içinde güvenli üçüncü bir ülkeye başvuru yapma hakkının saklı olduğu ve bu kişiyi sınırda reddetmenin geri göndermeme ilkesinin ihlali olmadığı iddiasıdır. $^{82}$

76 Michael Barutciski, "The Limits to the UNHCR's Supervisory Role", James C. Simeon (der.), The UNHCR and the Supervision of International Refugee Law, Cambridge, Cambridge University Press, 2013, s.66.

77 Tam Yetkili Temsilciler Konferans1, 16. Toplantı.

78 UNHCR, Advisory Opinion, s.2.

79 Roman Boed, "The State of the Right of Asylum in International Law", Duke Journal of Comparative \& International Law, Cilt 5, No.1, 1994, s.28.

80 Ibid., s.19.

81 Third party intervention by the Council of Europe Commissioner for Human Rights under Article 36, paragraph 3, of the European Convention on Human Rights. 9 Kasim 2015, para.9.

82 Daniel Thym, "Moving Towards Plan B: the Rejection of Refugees at the Border", EU Migration and Asylum Law Policy, 28 January 2016, http://eumigrationlawblog.eu/moving-towards-plan-b-the-rejection-of-refugees-at-the-border/ (Erişim Tarihi: 17 Haziran 2016). 


\section{Temel Haklara Erişim}

1951 Sözleşmesi devletlere mültecilere sağlanacak haklar konusunda ülkelerindeki yabancılara ya da vatandaşlarına tanıdığından daha az olamayacak yükümlülükler getirmektedir. Sözleşme’ye taraf devletler; ülkelerindeki mültecilere sağlanan uluslararası koruma çerçevesinde çalışma, eğitim, dini ibadet ve eğitim özgürlüğü, mülk edinme, dernek kurma, yargıya serbest erişim, sosyal güvenlik ve seyahat özgürlüğü haklarını tanımakla yükümlüdür. ${ }^{83}$ Ancak 1951 Sözleşmesi 42. Maddesi taraf devletlere ayrımcılık yapmama ve geri göndermeme ilkeleri ile dini ibadet ve eğitim özgürlügü ve yargıya serbest erişim dışındaki mülteciler lehine olan bütün hak doğurucu maddelere çekince koyma imkânı getirmiştir. Böylelikle taraf devletler mültecilerin temel haklara erişimi konusunda egemenliklerini sınırlamayarak yükümlülük altına girmemeyi tercih etme hakkına sahip olmuştur.

1951 Sözleşmesi inşacı bir yaklaşımla mültecilerin korunmasının ortak bir değer olarak devletlerin politikalarını şekillendirmesini amaçlamıştır. Ancak geri göndermeme ilkesine devletlerin yorumuna açık muğlâk ifadeler içeren istisnai bir hüküm eklenmiş, iltica hakkına hiç yer verilmemiş ve taraf devletlere mültecilere sağlanan temel haklar konusunda çekince koyma imkânı sunulmuştur. Mültecileri en iyi koruma yolu ise mültecilere kalıcı çözüm sağlayarak artık uluslararası koruma gereksinimini ortadan kaldırmaktır. Kalıcı çözümler, aynı zamanda 1951 Sözleşmesi’nin ikinci amacı olan sorumluluk paylaşımının da temelini oluşturmaktadır.

\section{Sorumluluk Paylaşımı}

1951 Sözleşmesi’nin önsözü, mülteci sorunuyla mücadele sorumluluğunun sadece belli devletlere yüklenmemesinin ancak uluslararası işbirliği ile mümkün olduğunu vurgulamaktadır. Ancak sorumluluk paylaşımının hukuki zemini oldukça zayıftır ve Sözleşme bu konuda, taraf devletleri bağlayan bir yükümlülük getirmemektedir. Mülteci sorununda sorumluluk almak istemeyen bir devlet, politikalarından dolayı sadece eleştirilebilmektedir. Devletlerin, ülkesinde mülteci barındıran bir devlete yardım etmek zorunluluğu olmasa da ev sahibi devletler yine de sorumluluğun paylaşılmasını beklemektedir. Ancak ne yazık ki asıl sorumluluk çoğu zaman ilk iltica devletine bırakılmaktadır. Örneğin 15 Şubat 2016 itibariyle, kayıt altına alınan Suriyeli mültecilerin \%90'ına sadece 3 devlet ev sahipliği yapmaktadır. Resmi rakamlara göre 4 milyon 715 bin mültecinin \%55’i Türkiye’de, \%22'si Lübnan'da ve \%13'ü Ürdün'de bulunmaktadır. ${ }^{84}$ Benzer bir dengesizlik, yapılan mali yardımlarda da görülmektedir. Örneği Şubat 2016 itibariyle ülkesindeki Suriyeli mülteciler için 10 milyar dolar harcayan Türkiye, ${ }^{85}$ uluslararası toplumdan sadece 418 milyon dolar yardım almıştır. ${ }^{86}$

Mültecilere kalıcı çözümler sunulması, sorumluluk paylaşımı açısından oldukça önemlidir. BMMYK'nın devletlerin işbirliği sayesinde mültecilere sağlayabileceği kalıcı çözümler üçüncü bir ülkeye yerleştirme, yerel bütünleşme ve gönüllü geri dönüştür. ${ }^{87}$ İlk iki çözümde sorumluluk diğer ülkelerde iken son çözümde ise kaynak ülkededir. Gönüllü geri dönüş seçeneğinde genellikle kaynak

83 Bkz. Md.17, 18, 22, 4, 13, 15, 16, 24 ve 26.

84 UNHCR, Syrian Regional Refugee Response, http://data.unhcr.org/syrianrefugees/regional.php (Erişim Tarihi: 15 Şubat 2016).

85 Doğan Haber Ajansı, "Davutoğlu: Kamplarda yaşayan mültecilere şimdiye kadar 10 milyar dolar harcadık", 4 Şubat 2016.

86 “Türkiye'de Mülteciler İçin Harcanan Para Dudak Uçuklatıyor”, 18 Eylül 2015, http://www.haberler.com/suriyekoordinasyon-toplantisi-7703735-haberi/ (Erişim Tarihi: 5 Kasım 2015).

87 Bkz. UNHCR, Framework for Durable Solutions for Refugees and Persons of Concern, 16 Eylül 2003, EC/53/ SC/INF.3. 
ülkenin mülteci vermesine sebep olan sorunun çözümüne ihtiyaç duyulduğu için, Sözleşménin amaçladığı sorumluluk paylaşımı ile üçüncü bir ülkeye yerleştirme ve yerel bütünleşme çözümlerinin kast edildiği söylenebilir.

Tanım itibariyle yeniden yerleştirme bir mültecinin iltica ettiği ülkeden, kalıcı oturma izni vermeye hazır bir başka ülkeye yerleştirilmesidir. ${ }^{88}$ Üçüncü bir ülkeye yerleştirilen mülteciler ve aileleri, kalıcı oturma izninin dışında geri gönderilmeme hakkına ve o ülke vatandaşlarının sahip olduğuna benzer başka birçok hakka sahip olmaktadır. Bu kalıcı çözüm aynı zamanda, mültecilerin yerleştirildiği ülkenin vatandaşı olma ihtimalini de barındırmaktadır. ${ }^{89}$ Mültecilere yeni bir hayat vadeden bu kalıcı çözüm sürecinde yetkili merci, tüzüğü ve BM Genel Kurulu kararları uyarınca BMMYK'dir. Ancak 1951 Sözleşmesi, yeniden yerleştirme konusunda devletlere bir yükümlülük getirmemiştir. Dolayısıyla bu konuda, mültecilerin ihtiyaçları ve durumlarının aciliyetinden ziyade devletlerin ulusal mevzuatları ve istekleri belirleyicidir..$^{90}$ Örneğin Irak vatandaşı iki kız kardeş, Sünni oldukları için Irak'taki Şii çoğunluk tarafından rahatsız edildikleri gerekçesiyle Suriye'ye kaçmış ve BMMYK tarafından mülteci oldukları kabul edilmiştir. Anneleri ve kız kardeşleri İngiltere'de olduğu için BMMYK, üçüncü bir ülkeye yerleştirme kapsamında bu iki kız kardeşin İngiltere'ye yerleştirilmeleri için başvurmuştur. Ancak İngiltere, ulusal yasalarının belirlediği yerleştirilme koşullarını yerine getirmedikleri gerekçesiyle BMMYK’nın talebini reddedebilmiştir. ${ }^{91}$

Geçtiğimiz 10 yılda yaklaşı 900,000 mülteci, yeniden yerleştirme programları çerçevesinde gelişmiş ülkelere yerleştirilmiştir. ${ }^{92} 2014$ yılında ülkesine mülteci almayı kabul eden üçüncü ülkeler, bir önceki yıla göre sadece 6800 kişi artışla toplam 105,200 mülteci almıştır. ${ }^{93}$ Kalıcı çözüm bekleyen toplam mülteci sayısıyla, yeniden yerleştirme kalıcı çözümüne kavuşan mülteci sayısı kıyaslandığında ise sorumluluk paylaşımının ne kadar yetersiz olduğu ortaya çıkmaktadır. Kalıcı çözüm için bekleyen mültecilerin sadece \%0,53’ü yeniden yerleştirme çözümüne erişebilmiştir. Nitekim BMMYK da, 2016 y1lında üçüncü bir ülkeye yerleştirilmesi ihtiyacı teyit edilen 1 milyon 153 bin mülteciden sadece 122 binini yerleştirebilmeyi planlamaktadır. ${ }^{94}$

Mülteci sorununda sorumluluk paylaşımı için önemli olan bir diğer kalıcı çözüm ise yerel bütünleşmedir. Yerel bütünleşme mültecinin ev sahibi toplumun hukuki, ekonomik, sosyal ve kültürel süreçler neticesinde tam anlamıyla bir üyesi haline gelmesiyle gerçekleşmiş sayılmaktadır. ${ }^{95}$ Yeniden yerleştirme kalıcı çözümünden farklı olarak yerel bütünleşme çözümü, 1951 Sözleşmesi'nin hükümleri arasında kendisine yer bulmaktadır. 34. maddeye göre Sözleşme’ye taraf devletlerin, ülkelerinde bulunan mültecilerin vatandaşlık almasını her türlü imkân nispetinde kolaylaştırmak için gayret etmesi gerekmektedir. Ancak yeniden yerleştirmede olduğu gibi yerel bütünleşme konusunda da devletler, egemenliklerini sınırlamamış ve Sözleşme metninde bağlayıcı bir yükümlülükten kaçınmıştır. Nitekim İngiltere de taslak metin üzerine yapılan görüşmeler sırasında bu maddedeki "her türlü imkân nispetinde" ve "gayret etmek" ifadelerinden yola çıkarak yerel bütünleşmenin devletler için

88 UNHCR, Global trends, 2015, s.25.

89 UNHCR, Refugee Resettlement Trends 2015, s.5.

90 UNHCR, Resettlement Handbook, Geneva, 2011, para.7.7

91 ST and ET v. Secretary of State for the Home Department; and Secretary of State for the Home Department v. C1 and C2, 28 Şubat 2014, EWCA Civ 188.

92 UNHCR, Global trends, 2014, s.9.

93 Ibid., s.21-22.

94 UNHCR Global Appeal 2016-2017, s.115.

95 UNHCR, Global trends, 2014, s.22. 
bağlayıcı bir yasal zorunluluk yerine sadece bir tavsiye niteliğinde olduğunu belirtmiştir. ${ }^{96}$ İngiltere'nin bu beyanı, BM bünyesindeki Geçici Komite ve BMMYK tarafından da desteklenmektedir. BM Mülteciler ve Vatansızlar Geçici Komitesi 1950 yılında yayınladığı memorandumda 34. maddeye göre devletlerin yerel bütünleşme ile ilgili kararlarının mutlak olduğunu; devletlere, ülkesinde bulunan bir mülteciye siyasi haklar da içeren birçok ayrıcalık veren bu kalıcı çözüm imkânını sunması için dayatma yapılamayacağını belirtmektedir. ${ }^{97}$ Sözleşme'nin 34. maddesiyle ilgili yorum sunan BMMYK da, Sözleşme’nin İngilizce metninde kullanılan ve zorunluluk ifadesi olan "shall" yardımcı fiilinin taraf devletlere "nitelikli" bir görev yükleyerek bir zorunluluktan ziyade bu kalıcı çözüme erişimi her türlü imkân ölçüsünde kolaylaştırma görevi verdiğini belirtmiştir. ${ }^{98}$

Taraf devletlerin egemenliklerini sinırlamadığı yerel bütünleşme çözümünde de, sorumluluk paylaşımı amacının uygulamada gerçekleşmediği görülmektedir. 20 yıl önce, gelişmekte olan ülkeler dünyadaki mültecilerin \%70'ine ev sahipliği yaparken 2014 sonu itibariyle bu oran \%86'ya (12,4 milyon) yükselmiştir. ${ }^{99}$ Kesin olmamakla birlikte 2014 yılı verilerine göre toplam 27 ülke ortalama 32,100 mülteciye vatandaşlık vermiştir. ${ }^{100} \mathrm{Bu}$ istatistikler ise kalıcı çözüm bekleyen toplam mülteci sayısıyla kıyaslandığında ihtiyacın \%0,2’sini dahi karşılamamaktadır.

Özetle, gelişmekte olan bölgeler giderek artan bir şekilde milyonlarca yeni mülteciyi ülkelerine alırken, yeniden yerleştirme ve yerel bütünleşme kalıcı çözümlerine kavuşan mülteci oranı ise \%1'e dahi ulaşamamıştır. Bir diğer ifadeyle, neoliberal anlayışın yansımalarının görüldügü ve devletler arasında işbirliği öngören sorumluluk paylaşımı amacı, bağlayıcı yükümlülüklerin yokluğunda yerini bir kez daha klasik realizmin savunduğu bireysel devlet politikalarına bırakmıştır.

\section{Sonuç}

Uluslararası bir rejim kapsamında devletlerin egemenliklerini sınırlamaları, çoğunlukla bir devletin tek başına çözemeyeceği ve uluslararası işbirliğine şiddetle ihtiyaç duyulan bir sorun için mümkündür. Her devleti değişen oranlarda da olsa etkileyen ve hiçbir devletin tek başına çözüm bulamayacağ uluslararası bir sorun olan mülteci sorunu da dünya siyasetini 2. Dünya Savaşı'ndan bu yana belki de hiç bu kadar işgal etmemiştir. Bu durumun bir sonucu olarak, 1. Dünya Savaşı'ndan sonra temelleri atılan ve 1951 Sözleşmesi’yle günümüzdeki şeklini alan uluslararası mülteci rejimine gerek mülteciler gerekse devletler bakımından belki de hiç bu kadar ihtiyaç hissedilmemiştir. İlk kez 2014 yılında, ülkelerinden zorla göç ettirilen kişi sayısı 2. Dünya Savaşı'ndan bu yana 50 milyonu geçmiş ve 2015 yılında rekor bir artışla nerdeyse 60 milyona yaklaşmıştır. Bu durumda her 122 kişiden birinin ülke içinde ya da dışında zorla yerinden edildiği sonucu ortaya çıkmaktadır. ${ }^{101}$

Mülteci sorunuyla ilgili, dünya kamuoyu mültecilerin ölümle kucak kucağa ilerleyen zorlu yolculuklarını ve ulaştıkları ülkelerdeki durumlarını tartışırken; siyasi liderler de sorumluluk paylaşımı ve uluslararası işbirliği mekanizmasını tartışmaktadır. Nitekim uluslararası mülteci rejiminin temelini

96 Tam Yetkili Temsilciler Konferansı, 16. Toplantı.

97 BM Mülteciler ve Vatansız Kişiler Geçici Komitesi, Genel Sekreter Memorandumu, 3 Ocak 1950, E/ AC.32/2, Md.28.

98 UNHCR, Commentary on the Refuge Convetion 1951, Articles 2-11, 13-37, 1997, http://www.unhcr. org/3d4ab5fb9.pdf (Erişim Tarihi: 17 Haziran 2016), Md.34, Yorum 2.

99 UNHCR, Global Trends, 2015, s.18.

100 UNHCR, Global Trends, 2015, s.27.

101 UNHCR, Worldwide Displacement Hits All-time High as War and Persecution Increase, News Stories, 18 Haziran 2015. 
oluşturan 1951 Sözleşmesi de, mülteci sorunun insani ve siyasi bu iki yüzünü ele almayı amaçlamıştır. Sözleşme'nin hazırlanmasındaki ilk amaç mültecilere uluslararası koruma sağlanması iken ikinci amaç da sorumluluk paylaşımı mekanizmasıyla mülteci sorununun sadece belli devletlerin omuzlarına yük bindirerek devletler arası bir gerilime yol açmasının engellenmesi olmuştur. Ancak rejimin günümüzde geldiği nokta, devletlerin mültecilere uluslararası koruma sağlanması ve sorumluluk paylaşımı konusunda isteksiz politikaları nedeniyle bu iki amacın da gerçekleştirilemediğini göstermektedir. Bir başka deyişle, mültecilere uluslararası koruma ve kalıcı çözüm sağlanması amacıyla kurulan uluslararası mülteci rejiminin varlı̆̆ına rağmen taraf devletler mülteci sorununa yönelik politikalarını halen bireysel olarak şekillendirebilmektedir. Bu durumun nasıl mümkün olduğunu sorgulamayı amaçlayan bu çalışma ise 1951 Sözleşmesi'nin yapısını incelemekte ve Koskenniemi'nin siyasi gerçeklik ve normatif düzen ikileminden faydalanmaktadır.

Çalışma, ilk olarak, Koskenniemi’nin siyasi gerçeklik ve normatif düzen ikilemi, rejim kuramları ve uluslararası mülteci rejiminin tarihsel gelişimi ve amaçlarını hakkında gerekli bilgileri vermektedir. Çalışmaya göre, 1951 Sözleşmesi amacı itibariyle neoliberal bir normatif düzen öngörürken yapısı itibariyle ise klasik realist anlayışın hâkim olduğu siyasi gerçekler arasında kalmaktadır. Çalışma ilgili literatürü taradıktan ve araştırma sorusunun literatüre katkısını gösterdikten sonra Sözleşme’nin yapısını incelemektedir. Mülteci tanımının ve mülteci statüsü alamayacak kişilerin unsurlarını taraf devletlere sunduğu dar yorum imkânı ve açısından sorgulayan çalışma, Sözleşme'nin taraf devletlere ilgili konularda kararlarını kendi davranışlarına, çıkarlarına ve isteklerine göre şekillendirebilme imkânı sunduğu sonucuna ulaşmaktadır. Sözleşme’nin iki amacından ilki olan mültecilere uluslararası koruma sağlama ile ilgili geri göndermeme ilkesini, iltica hakkı tartışmasını ve temel haklara erişimi inceleyen çalışma son olarak ise ikinci amaç olan sorumluluk paylaşımını sorgulamaktadır. Mülteci tanımında "zulüm” kavramının tanımlanmaması, "haklı sebeplerle korkmak" ve "belli bir sosyal gruba aidiyet” gibi muğlâk ve yoruma açık ifadeler kullanılması; kimin mülteci olamayacağı ile ilgili "ciddi kanaat" ve "ağır bir genel suç" gibi muğlâk ifadelerin varlığı kime mülteci statüsü verileceği konusunda devletlerin kontrolü ellerinde tutmalarına imkân sağlamıştır. Mültecilere uluslararası koruma sağlanmasının temelini oluşturan iltica hakkına Sözleşme'de hiç yer verilmemesi, mültecilere temel haklar sağlama yükümlülüklerine çekince koyulabilmesi (Md.42) ve ulusal güvenlik ve kamu düzeni gibi yoruma müsait nedenlerle mültecileri sınır dışı edebilme imkânı (Md.32) devletlerin bireysel kontrolünü uluslararası koruma konusunda da mümkün kılmıştır. Hakların ulusal güvenlik sebebiyle geçici olarak askıya alınabilmesi (Md.9) ve geri göndermeme kuralına istisnalar konulması (Md.33) ise devletlerin, mülteci sorunun yaratabileceği olası dış tehditlere karşı kendilerini koruma amacına hizmet etmektedir. Kalıcı çözümler için devletlere bağlayıcı yükümlülükler getirilmemiş, sorumluluk paylaşımının temelini oluşturan yeniden yerleştirme seçeneği Sözleşme’de hiç yer almamıştır. Sözleşme'de yer alan yerel bütünleşme kalıcı çözümü ise "her türlü imkân nispetinde" ve "gayret ederler” ifadeleriyle (Md.34) klasik realist kuramın öngördüğü gibi devletlerin egemenliklerinin sınırlanmasına ve uluslararası işbirliği yükümlülüğü altına girmeye yanaşmadığının bir diğer göstergesi olmuştur.

Özetle Sözleşme; kurmayı öngördüğü normatif düzene rağmen, mülteci ve devletlerin ortak yararı yerine taraf devletlerin bireysel davranışları, istekleri ve çıkarlarına göre şekillenebilecek bir yapıya sahiptir. Her ne kadar muğlâk ve göreceli ifadeler Sözleşme’nin değişen şartlara uyum gösterebilmesi için gerekli olsa da devletler kendilerine tanınan bu yorum esnekliğini, yükümlülüklerini siyasi gerçeklere göre şekillendirmek için kullanmaktadır. 


\section{Kaynakça}

Barutciski, Michael. "The Reinforcement of Non-Admission Policies and the Subversion of UNHCR: Displacement and Internal Assistance in Bosnia-Herzegovina (1992-94)", International Journal of Refugee Law, Cilt 8, No.1/2, 1996, s.49-110.

Barutciski, Michael. “The limits to the UNHCR's supervisory role”, James C. Simeon (der.), The UNHCR and the Supervision of International Refugee Law, Cambridge, Cambridge University Press, 2013, s.59-74.

Basok, Tanya. "Refugee policy: Globalization, radical challenge, or state control?", Studies in Political Economy, No.50, 1996, s.133-166.

Betts, Alexander. Forced Migration and Global Politics, West Sussex, Wiley-Blackwell, 2009.

BM Genel Kurulu Kararı, No.319, 3 Aralık 1949.

BM Mülteciler ve Vatansız Kişiler Geçici Komitesi, 40. Toplantı, Özet Tutanakları, 22 Ağustos 1950, E/AC.32/SR.40.

BM Mülteciler ve Vatansız Kişiler Geçici Komitesi, Genel Sekreter Memorandumu, 3 Ocak 1950, E/ AC.32/2, http://www.refworld.org/docid/3ae68c280.html (Erişim Tarihi: 17 Haziran 2016).

BM Mültecilerin ve Vatansız Kişilerin Hukuki Durumu Hakkında Tam Yetkili Temsilciler Konferansı, 15. Toplantı, Özet Tutanakları, 23 Kasım 1951, A/CONF.2/SR.15, http://www.refworld.org/docid/3ae68cdb54.html (Erişim Tarihi: 15 Nisan 2015).

BM Mültecilerin ve Vatansız Kişilerin Hukuki Durumu Hakkında Tam Yetkili Temsilciler Konferansı, 16. Toplantı, Özet Tutanakları, 23 Kasım 1951, A/CONF.2/SR.16, http://www.refworld.org/docid/3ae68cdc14.html (Erişim Tarihi: 15 Nisan 2015).

BM Mültecilerin ve Vatansız Kişilerin Hukuki Durumu Hakkında Tam Yetkili Temsilciler Konferansı, 19. Toplantı, Özet Tutanakları, 26 Kasım 1951, A/CONF.2/SR.19, http://www.refworld.org/docid/3ae68cda4 (Erişim Tarihi: 15 Nisan 2015).

BM Mültecilerin ve Vatansız Kişilerin Hukuki Durumu Hakkında Tam Yetkili Temsilciler Konferansı, 29. Toplantı, 28 Kasım 1951, A/CONF.2/SR.29, A/CONF.2/SR.29, http://www.refworld.org/docid/3ae68cdf4.html (Erişim Tarihi: 15 Haziran 2016).

Boed, Roman. "The State of the Right of Asylum in International Law", Duke Journal of Comparative \&" International Law, Cilt 5, No.1, 1994, s.1-34.

Bruin, Roland H. M. "Working Party on Non-State Agents of Persecution: 2002 Report", 5th IARLJ Conference, Yeni Zelanda, 2002, s.451-456.

Chimni, Bhupinder S. “The Geopolitics of Refugee Studies: A View from the South”, Journal of Refugee Studies, Cilt 11, No.4, 1998, s.350-374.

Doğan Haber Ajansı. "Davutoğlu: Kamplarda yaşayan mültecilere şimdiye kadar 10 milyar dolar harcadık”, 4 Şubat 2016.

Ergüven, Nasıh S. ve Beyza Özturanlı. "Uluslararası Mülteci Hukuku ve Türkiye”, AÜHDF, Cilt 62, No.4, 2013, s.1007-1061.

Frelick, Bill. "Preventive Protection and the Right to Seek Asylum: A Preliminary Look at Bosnia and Croatia", International Journal of Refugee Law, Cilt 4, No.4, 1992, s.439-454.

Gallagher, Dennis. "Durable solutions in a new political era”, Journal of International Affairs, Cilt 47, No.2, 1994, s.429-50.

Geovanni Hernandez-Montiel v. Immigration and Naturalization Service, United States Court of Appeals for the Ninth Circuit, 24 Ağustos 2000, A72-994-275, http://www.refworld.org/docid/3ba9c1119.html (Erişim Tarihi: 10 Ekim 2015). 
Gibney, Matthew J. "Security and the Ethics of Asylum after 11 September”, Forced Migration Review, No.3, 2002, s.40-42.

Gil-Bazo, María-Teresa. "Asylum as a General Principle of International Law”, International Journal of Refugee Law, Cilt 27, No.1, 2015, s.3-28.

Guterres, António. “Preserving Life, amidst turmoil”, UNHCR Global Appeal 2015 Update, http://www.unhcr. org/ga15/index.xml (Erişim Tarihi: 1 Ocak 2016).

Hopf, Ted. "The Promise of Constructivism in International Relations Theory”, International Security, Cilt 23, No.1, 1998, s.171-200.

Human Rights Watch. Unwelcome Guests, Iran's Violations of Afghan Refugee and Migrant Rights, 20 Kasım 2013.

International Organization for Migration, Mediterranean Migrant Deaths Reach 374; Arrivals in Greece Top 68,000 in 2016, Press Release, 5 Şubat 2016.

In re Fauziya Kasınga. Applicant File A73 476 695, 13 Haziran 1996, Interim Decision No 3278, s.358-359, http://www.justice.gov/sites/default/files/eoir/legacy/2014/07/25/3278.pdf (Erişim Tarihi: 10 Ekim 2015).

"Islam v. Secretary of State for the Home Department"; R v. Immigration Appeal Tribunal and Another, ex parte Shah, 25 March 1999, http://www.refworld.org/pdfid/3dec8abe4.pdf (Erişim Tarihi: 12 Ekim 2015).

Jastram, Kate ve Irene Khan. "Refugee Protection: A Guide to International Refugee Law”, UNHCR, http:// www.unhcr.org/3d4aba564.html (Erişim Tarihi: 14 Ekim 2015).

Kälin, Walter. "Non-state agents of persecution and the inability of the state to protect", Geo. Immigr. LJ, No15, 2000, s.415-431.

Keely, Charles B. "How Nation-States Create and Respond to Refugee Flows", International Migration Review, Cilt 30, No.4, 1996, s.1046-1066.

Koser, Khalid. International Migration A Very Short Introduction", Oxford, Oxford University Press, 2007.

Koskenniemi, Martti. From apology to utopia: the structure of international legal argument, Cambridge, Cambridge University Press, 2006.

Krasner, Stephen D. "Structural causes and regime consequences: regimes as intervening variables", Stephen D. Krasner (der.), International Regimes, Ithaca, Cornell University Press, 1983, s.1-21.

Legal Report on Access to Healthcare in 12 Countries, 8 Haziran 2015, https://mdmeuroblog.files.wordpress. com/2014/05/mdm-legal-report-on-access-to-healthcare-in-12-countries-3rd-june-20151.pdf (Erişim Tarihi: 1 Ekim 2015).

Loescher, Gil. “The international refugee regime: Stretched to the Limit?", Journal of International Affairs, Cilt 47, No.2, 1994, s.351-377.

Loescher, Gil, “UNHCR and the Erosion of Refugee Protection”, Forced Migration Review, No.10, 2001, s.28-30.

Martin, Lisa L. "Neoliberalism”, Tim Dunne et.al. (der.), International Relations Theories: Discipline and Diversity, New York, Oxford University Press, 2007, s.109-126.

Mercer, Jonathan. “Anarchy and Identity”, International Organization, Cilt 49, No.2, 1995, s.229-252.

“Mission Impossible: UNHCR says no to forced repatriation of refugees", The Express Tribune, 14 Nisan 2015.

Morgenthau, Hans. Politics Among Nations, New York, Knopf, 2001.

"Mugesera v. Canada", 28 Haziran 2005, 2005 SCC 40, http://www.refworld.org/docid/470a4a6bla. html (Erişim Tarihi: 10 Ekim 2015).

Noll, Gregor. “Seeking Asylum at Embassies: A Right to Entry under International Law?", International Journal of Refugee Law, Cilt 17, No.3, 2005, s.542-573. 
O'Nions, Helen. Asylum-a Right Denied: A Critical Analysis of European Asylum Policy, Surrey, Ashgate Publishing, 2014.

Refugee Appeal No. 1312/93, Re GJ, No 1312/93, http://www.refworld.org/docid/3ae6b6938.html (Erişim Tarihi: 10 Ekim 2015).

Roberts, Adam. "More Refugees, less Asylum: A Regime in Transformation”, Journal of Refugee Studies, Cilt 2, No.4, 1998, s.375-395.

Schoenholtz, Andrew I. "New Refugees and the Old Treaty: Persecutors and Persecuted in the Twenty-First Century", Chicago Journal of International Law, Cilt 16, No 1, 2015, s.81-126.

“SGDB v. Minister for Immigration \& Multicultural \& Indigenous Affairs", 15 March 2004, S 590 OF 2003, http://www.refworld.org/docid/4110ce034.html (Erişim Tarihi: 1 Ekim 2015).

"ST and ET v. Secretary of State for the Home Department; and Secretary of State for the Home Department v. C1 and C2", 28 Şubat 2014, EWCA Civ 188, http://www.refworld.org/docid/5315aa4f4.html (Erişim Tarihi: 15 Ekim 2015).

Sterling-Folker, Jennifer. "Liberalism”, Jennifer Sterling-Folker (der.), Making Sense of International Relations Theory. Boulder, Lynne Rienner Publishers, 2006, s.55-61.

Suhrke, Astri. "Burden-sharing during refugee emergencies: The logic of collective versus national action", Journal of Refugee Studies Cilt 11, No.4, 1998, s.396-415.

Sztucki, Jerzy. "The Conclusions on the International Protection of Refugees Adopted by the Executive Committee of the UNHCR Programme", International Journal of Refugee Law, Cilt 1, No.3, 1989, s.285-293.

Third party intervention by the Council of Europe Commissioner for Human Rights under Article 36, paragraph 3, of the European Convention on Human Rights, Council of Europe, Commissioner for Human Rights, 9 Kasim 2015.

Thym, Daniel. "Moving Towards Plan B: the Rejection of Refugees at the Border", EU Migration and Asylum Law Policy, 28 January 2016, http://eumigrationlawblog.eu/moving-towards-plan-b-the-rejection-ofrefugees-at-the-border/ (Erişim Tarihi: 17 Haziran 2016).

“Türkiye'de Mülteciler İçin Harcanan Para Dudak Uçuklatıyor”, 18 Eylül 2015, http://www.haberler.com/ suriye-koordinasyon-toplantisi-7703735-haberi/ (Erişim Tarihi: 5 Kasım 2015).

“T v. Secretary of State for the Home Department”, 22 Mayıs 1996, 2 All ER 865, http://www.refworld.org/ docid/3ae6b70f4.html (Erişim Tarihi: 10 Ekim 2015).

"UN: Forced Repatriation of Somalis in Dadaab Violates International Law", Hiiraan Online, 16 Nisan 2015.

UNHCR. Advisory Opinion on the Extraterritorial Application of Non-Refoulement under the 1951 Convention.

UNHCR. Commentary on the Refuge Convetion 1951, Articles 2-11, 13-37, 1997, http://www.unhcr. org/3d4ab5fb9.pdf (Erişim Tarihi: 17 Haziran 2016).

UNHCR. Framework for Durable Solutions for Refugees and Persons of Concern, 16 Eylül 2003, EC/53/SC/INF.3.

UNHCR Global Appeal 2016-2017.

UNHCR. Global trends, Forced Displacement in 2014.

UNHCR. Global trends, Forced Displacement in 2015.

UNHCR. Mid-Year Trends 2015.

UNHCR. Refugee Resettlement Trends 2015.

UNHCR. Resettlement Handbook, Geneva, 2011.

UNHCR. Re: Request for Advisory Opinion, 6 Ocak 2006, http://www.refworld.org/pdfid/43de2da94.pdf (Erişim Tarihi: 18 Haziran 2016). 
UNHCR. States parties to the 1951 Convention relating to the Status of Refugees and the 1967 Protocol, http:// www.refworld.org/docid/4ec4a7f02.html (Erişim Tarihi: 15 Mayıs 2014).

UNHCR. Syrian Regional Refugee Response, http://data.unhcr.org/syrianrefugees/regional.php (Erişim Tarihi: 15 Şubat 2016).

UNHCR. The Principle of Non-Refoulement as a Norm of Customary International Law.

UNHCR. UNHCR concerned at reports that asylum seekers, including Syrians, denied entry to some EU countries, News Stories, 15 Kasım 2013.

UNHCR. Worldwide displacement hits all-time high as war and persecution increase, News Stories, 18 Haziran 2015.

Wendt, Alexander. "Anarchy Is What States Make of It: The Social Construction of Power Politics", International Organization, Cilt 46, No.2, 1992, s.391-425.

Wirth, Anna, Cara Defilippis ve Jessica Therkelsen. “Global Refugee Work Rights Report”, Eylül 2014.

Zolberg, Aristide R. ve Peter M. Benda (der.). Global Migrants, Global Refugees: Problems and Solutions, Oxford, Berghahn Books, 2001. 